\title{
OBITUARY
}

\section{WALTER KJELLMAN}

The sudden death, from a cerebral tumour, of Mr Walter Kjellman, Director of the Swedish Geotechnical Institute, is a very great loss, not only to his Institutc and to Swcdish engineering, but to international soil mechanics, in which he was one of the leading personalities.

Mr Kjellman was born on 29 th November, 1905 , and obtained his degree in civil engineering at the Royal Institute of Technology, Stockholm, in 1928. From 1930-1936-except for a short period between 1930-31 when he was engaged in investigations in Terzaghi's laboratory, Vienna-he was employed by Messrs Vattenbyggnadsbyrån, Stockholm, working on the IIydro-Electric Power Plant Svir 3, in Russia. In 1938 he became geotechnist at the Board of Roads and Waterways in Sweden, and when the Royal Swedish Institute was formed in 1944 he was made its director. He was elected a member of the Swedish Geotechnical Institute in 1954.

The Polhem Prize was awarded to Mr Kjellman in 1936 by the Swedish Association of Engineers and Architects for his apparatus for consummate investigations of the mechanical properties of soils, and this is still the only existing non-symmetrical triaxial apparatus in which principal stress can be varied independently of the others. Amongst other important methods and apparatuses for which he was responsible, are the cardboard wick method for vertical drainage, and the soil sampler with metal foils for taking undisturbed cores of great length, which is still being used in nine countries. His alert mind and logical deductions occasionally resulted in unconventional ideas which he was not afraid to discuss, as was shown in his recent Paper in Géotechnique, "Do Slip Surfaces Exist? ", and in his last Paper " Unorthodox Thoughts about Filter Criteria." It was whilst preparing for a journey to Yugoslavia, where he was to give a series of lectures in which the latter Paper featured, that he collapsed.

The establishment of an international geotechnical literature service, to be located at a central point, in which literature in each science could be managed by its own specialists, was the ambition of Mr Kjellman, and this subject was discussed by the Executive Committee of the International Society of Soil Mechanics and Foundation Engineering at the Zurich Conference, which declared in its favour.

\section{LIST OF THE MORE IMPORTANT PAPERS BY W. KJELLMAN}

KJEllman, W., 1936. Report on an Apparatus for Consummate Investigation of the Mechanical Properties of Soils. Proc. 1st Int. Conf. Soil Mech., 2:16.

KJellman, W., 1940. Sakerhetsproblemet ur principiell och teoretisk synpunkt (The problem of safety from fundamental and theoretical point of view). Proc. Roy. Swed. Inst. Engng Res., Stockholm, No. 156 .

KJellman, W., 1948. Accelerating Consolidation of Fine-Grained Soil by Means of Card-Board Wicks. Proc. 2nd Int. Conf. Soil Mech., $2: 302$.

KJellman, W., Kallstenius, T., and Wager, O., 1950. Soil Sampler with Metal Foils. Device for Taking Undisturbed Samples of Very Great Length. Proc. Roy. Swed. Geot. Inst., No. 1.

Kjellman, W., and Liljedahl, Y., 1951. Device and Procedure for Loading Test on Piles. Proc. Roy. Swed. Geot. Inst., Stockholm, No. 3.

Kuellman, W., 1952. Consolidation of Clay Soil by Means of Atmospheric Pressure. Proc. Conf. Soil Stabil., Mass. Inst. Technol., Cambridge, Mass., p. 258.

Kuellman, W., Cadling, L., and Flodin, N., 1953. A New Geotechnical Classification System. Proc. Roy. Swed. Geot. Inst., Stockholm, No. 6.

KJeliman, W., 1954. Do Slip Surfaces Exist? proc. Europ. Conf. Stabil. Earth Slopes, Stockholnu, $1: 14$, and Géotechnique (1955), $5: 1: 18$.

KJeliman, W., Kallstenius, T., and Liljedahd, Y., 1955. Accurate Measurement of Settlements. Proc. Roy. Swed. Geot. Inst., No. 1, Stockholm. (In press.)

KJELLMAN, W., 1955. Unorthodox Thoughts about Filter Criteria. Report prepared for a lecture in Yugoslavia in October 1955. 


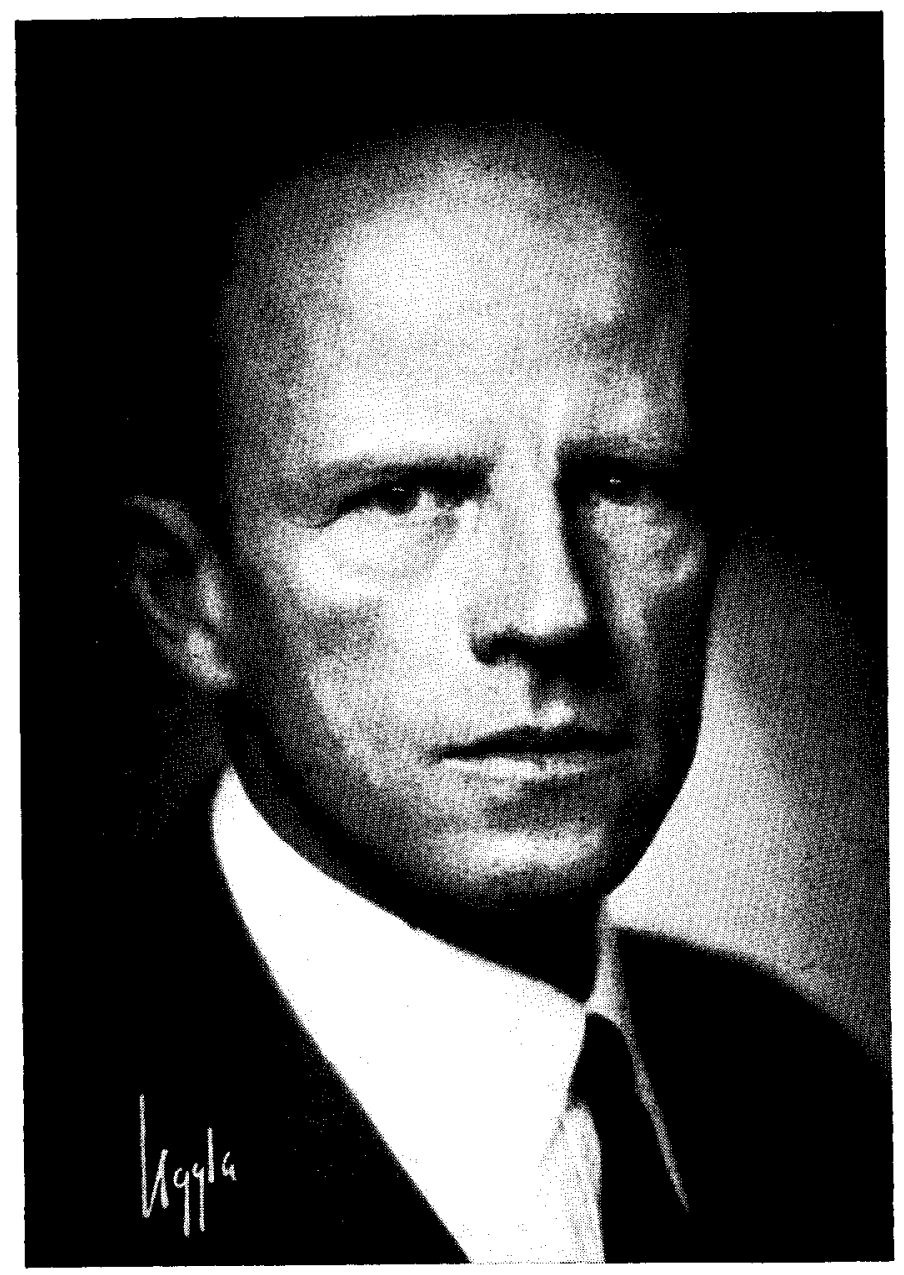

Walter Kjellman 